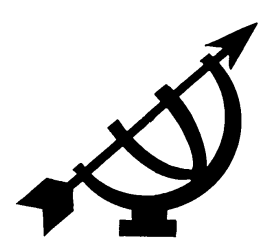

\title{
Struggle in the ethics of technology
}

\author{
Egbert Schuurman \\ Breukelen \\ NEDERLAND \\ E-pos: eschuurman37@hetnet.nl
}

\begin{abstract}
\section{Struggle in the ethics of technology}

The advantages as well as the disadvantages of modern technology, especially in combination with the development of the natural sciences, call in general for philosophical reflection. There is a struggle going on between the various philosophical movements. What is the content of Christian-philosophical thinking about technology and its problems? And what are the consequences in relation to the ethics of technology?
\end{abstract}

Such questions are very unusual among Christians. Nevertheless, the potentially disastrous effects of technology require an ethics of technology. Such an ethics must concern itself with man's good and responsible conduct in and through technology.

Generally speaking, since modern times there has been a technological control mentality. All questions relating to spiritual reflection and religious problems are ruled out. The world view has been transformed to a technological worldview. Motives, values and norms are derived from it. This implies a technological ethics which is the cause of many threats and problems. It is characterised by a cosmological deficit and an ethical deficit. It is only possible to overcome these deficits by a reorientation in culture and in ethics. The "Enlightenment" ought to be enlightened itself by the God-given revelation. The cosmology of the reality as God's creation and the commandments of love give a possibility for the redirection of an ethics of technology.

A responsible cultural and technological development evokes a representation of culture that depicts earth as a garden tended by humans. Technology must be developed within the perspective of the earth as one large garden-city. Technology ought to serve life and not to threaten it. 
Besides, in an ethics of responsibility attention is given to the central motive of love against the central motive of power of the technological worldview. For a justified, responsible technology the ethical challenge is finding not only true motives, but also environment values, technological values and social values. Furthermore, technology has to obey a large number of normative principles and related norms.

At the end of the article attention is paid to the consequences for praxis of this ethical-philosophical view and to the differences from those views which are currently held. The perspective of an ethics of technology ought not to be on doing things right, but on doing the right things.

\section{Opsomming}

\section{Die stryd om die etiek van tegnologie}

Die voor- sowel as die nadele van moderne tegnologie, in kombinasie met die ontwikkeling van die Natuurwetenskappe, skep die aanvraag na filosofiese denke. Daar is tans onenigheid tussen die verskeie filosofiese bewegings. Wat is die inhoud van Christelik-filosofiese denke oor tegnologie en tegnologies verwante probleme?

Christene vind hierdie tipe vrae ongewoon. Nietemin, die potensieel verwoestende gevolge wat tegnologie inhou, vra vir 'n goeie etiek van die tegnologie. Hierdie etiek moet die mens se verantwoordelike gedrag verwoord.

Vanaf die moderne tyd is daar 'n algemeen tegnologiesgekontroleerde mentaliteit. Alle vrae rondom spirituele inkeer en religieuse probleme word uitgeskakel. Daar is geen plek vir waardes, norme en motiewe nie. Hierdie tipe tegnologiese etiek impliseer vele probleme en bedreigings. Dit word gekenmerk deur 'n kosmologiese sowel as 'n etiese tekort. 'n Reoriëntasie van kultuur en etiek blyk die enigste oplossing vir hierdie probleem te wees. Die "Verligting" moet self verlig word deur 'n godgegewe openbaring. 'n Kosmologie van die werklikheidas God se skepping en die gebod van liefde, mag moontlik dien om die etiek van tegnologie te rig.

Verantwoordelike kulturele en tegnologiese ontwikkeling verwoord 'n kultuur wat die aarde as 'n tuin voorstel wat deur die mens versorg moet word. Die perspektief van die aarde as 'n reuse tuinstad moet dus gehandhaaf word waar tegnologiese ontwikkeling ter sprake kom. Tegnologie moet die menslike lewe dien en bevoordeel en dit nie bedreig nie.

In 'n etiek wat gekenmerk word deur verantwoordelikheid, word aandag gegee aan die sentrale motief van liefde, teenoor die sentrale motief van mag van die tegnologiese lewensvisie. Om 
regverdige en verantwoordelike tegnologie te bewerkstellig, is die etiese uitdaging om ware motiewe, omgewingswaardes, tegnologiese en sosiale waardes in praktyk te bring. Tegnologie moet ook heelwat ander normatiewe beginsels en verwante norme gehoorsaam.

Aan die einde van die artikel word aandag gegee aan die gevolge vir die praktyk van hierdie eties-filosofiese perspektief, en aan die verskille daarvan met huidige perspektiewe. Die perspektief vir 'n etiek van tegnologie moet dus nie wees om die dinge reg te doen nie, maar om die regte dinge te doen.

\section{Introduction}

The current techno-economic development has already realised many promises and offers many promises for the future. People can, however, be blinded by this development, preventing them to appreciate the seriousness of its potential disastrous effects. I suspect that this results from an uncritical attitude toward technology. But it is my conviction that it will progressively become clear that the most central problem in our culture is constituted by the stance towards or the view of technological development. Technology contributes to the quality of life, is a statement frequently heard. But it is rarely said that the opposite could also be true. What is our attitude toward technology that, on the one hand, identifies with the world, but on the other hand, alienates us from the world? This, in short, is the problem of modern technology. Because technology is the product of the Judeo-Christian tradition, the big question is: Does this tradition say anything about the essential ethics of technology?

\section{Ethics of technology is necessary}

\subsection{New situation: technological culture}

The necessity of an ethics of technology is not self-evident to everybody and therefore an explanation is required.

In comparison with, for example a century back, we are in a completely new situation. The modern, science-drenched technology which has unfolded enormously, has left its imprint on culture and has become a world encompassing system. In modern technology everything is connected to everything else and thus constitutes the technical milieu. Think away technology, and our whole culture collapses - especially the connection between technology and economic enterprises which has developed at a 
tremendous rate. It means that modern technology and economy are so tightly interwoven that the two have virtually become one portfolio.

Therefore, although I request attention for the ethics of technology, the ethics of economics cannot be separated from it. As we will see, they are connected by an extreme technical mentality or spirit which generates problems in the ethics of both. This has to be explained.

\subsection{Advantages}

He who compares our times with a few centuries back, notices the great advantages of modern technology. The average lifespan has been increased. Sewage and water purification lead to a healthier environment. Mechanising, automation and robotisation have relieved humans from hard manual and routine labour. The material wealth is unprecedented. We thankfully make use of many medical techniques that cure diseases. The hunger of many has been stilled. The modern means of communication supply us with ample information. Briefly, the possibility to make our wishes a reality has increased enormously.

\subsection{The shadowy side: problems and threats}

In the present culture the shadowy side of the scientifictechnological development becomes clearer. The technological control motive penetrates and directs the culture. It permeates many, if not all, aspects of society and infiltrates the human experiential world as a matter of course. Culture is thereby conveniently reduced to that which technology, science and economy can offer.

Western man has, as time passes, subjected himself to limitless technical manipulation and economic exploitation of reality, but with a massive threat of the destruction of the very basis of human existence. The current technological development threatens the sustainability of the natural environment and of the biosphere. The relevant values are simply ignored.

\subsection{Vulnerable technology}

The technical development also experiences threats from within. Large-scale technical developments regularly prove to be vulnerable as a result of human error or as a result of bad technical functioning, 
and confront us with far-reaching consequences. Technology can become a disaster by means of terrorism or errorism.

\subsection{Power over technical power}

While man was formerly threatened especially by nature, he now also has to face the threat of technology. Through technology man attempts to gain control over everything. The pressing question, however, is: how can we continue to control technology? How can we contain and control technical power? That is an ethical question par excellence.

\section{What is ethics?}

There are many definitions of ethics. Luckily they partially overlap one another resulting in a large measure of agreement despite the differences. In ethics there is reflection on the good and responsible actions of man. An ethics of technology must therefore concern itself with man's good and responsible conduct in and through technology, i.e. man must fulfill the normative aspects of reality within which technology functions.

Who is man and what constitutes good and accountable actions? Reactions to the answers to these questions as well as to the question concerning the place of technology in the entire spectrum of reality, diverge easily. That concerns the basis of an ethics: it has to do with differences in philosophical vision and with the background differences in philosophies of life and world views. These differences currently aggravate the task concerning ethics, because there is no unity of vision of man, history, the meaning of technology, culture or the future. While a common value and conception of norm is required, we are confronted by a divergent pluralism. But is it, notwithstanding these differences, possible to discern a main theme present in the spiritual background?

\section{Spiritual-historical background}

In a discussion of the problems and threats of the Technological Era, people restrict themselves to the symptoms. An in-depth discussion is necessary in order to include deep-seated and longstanding causes.

Schuurman indicated that, under the influence of the Renaissance, and in particular the Enlightenment, modern philosophy and modern thinking became increasingly a scientific-technological mentality. 
Man as "lord and master" - a term used by Descartes, the father of modern philosophy - articulates technological rationality by which the natural sciences and the technical sciences are used as instruments under the pretension that everything can be manipulated in order to solve problems relating to man and culture. It was especially the ideas of Frances Bacon that kept alive the utopia which promised a return to the lost paradise by means of scientific-technological advance.

The technological control mentality originates in man's pretense of being autonomous. He desires to strengthen his freedom by means of scientific-technological command. All problems are considered to be solvable by this mentality. In a sense only those problems are recognised that can be solved through science and technology. All questions relating to spiritual reflection and religious problems are ruled out. The technological culture therefore is accompanied by secularisation, with spiritual emptiness on a scale previously unheard of. The result is that culture is wholly saturated by the technological way of thinking or the technological mentality. Society is experiencing its influence in many sectors. The whole complex of science, technology and economy is being influenced by an overexcited technological spirit.

\section{The technological world view}

As a result of the absolutisation of technological thought much of reality is lost. That which does not fit into the technological model is disregarded or forgotten. The world view has been transformed to a technological world view by this development. Similar to the technological development, this world view is not static. On the contrary, each new technological development - e.g. those resulting from discoveries and innovations - make the world view dynamic and more easily adaptable. The technological world view is therefore continually changed by technological development. It is, however, a human construct and functions as a cultural paradigm. It is a type of framework within which people think and act. It has normative meaning. Motives, values and norms are derived from the technological world view. It therefore also forms an ethical framework. It has increasingly marked the development of Western culture and it is also marking the current globalisation.

\section{Current ethical recipe (motives, values and norms)}

The technological world view not only causes specific problems, but is mostly also decisive for the ethical solutions sought. By means of 
the technological world view there is coherence in the current approach. Ethics finds difficulty in freeing itself from the technological system. The current recipe for the treatment of technological problems is an attempt to investigate "cases" in order to develop rules of thumb for the future. Man seldom goes back to the roots of the problem and to the connection between problems. This results in the frequent trading of one problem for another, because people are caught in a type of technological labyrinth. The current ethics of technology prevents them from taking risks by acting in a controlled and cautious way. I have once called this the technical ethics. Ethics becomes a technique, because people attempt to streamline and guide technological development. A "technological control perspective" then dominates the ethics of technology. The problems in technological development are somewhat softened by this ethics. In a certain sense this state of affairs confirms - according to Habermas - what can be termed the ideology of technology. The ideology, inspired by the Enlightenment, implicates viewpoint-restricting limitations. Fundamental or essential questions are excluded, for instance questions concerning the background to technological development, questions regarding the origin, meaning, motives, values and norms for technology.

The main motive in this fundamental ethical attitude is that of striving for power over reality. This power has the pursuit of technical artificiality as its dominating value.

The concomitant implicit values are those of man being lord and master, the human passion for control, technological progress, (economic) self-interest and, in coherence with that, growing consumption as added-value: that is to say, benefit for all. No attention is given to the ecological values and social context. At most these subsequently receive political attention.

The norms that follow from the values of the technological world view are effectiveness, normalisation or standardisation, efficiency, success, maximum profit, with no or insufficient attention given to the cost to humanity, society and the environment.

We continually encounter more problems in which the technological world view and its ethics fail us. This is clear from problems concerned with sustainability. Sustainability means meeting the requirements of the present generation, without possibly jeopardising the ability of coming generations to fulfill their needs. Why is sustainability under pressure? 
The commanding technological world view dominates the current economy via a control model, which from the start, forces one-sided growth. In this development sustainability cannot be reached. In the context of environmental problems we may advance one step by means of environmental technology, but this step is nullified in subsequent development, because the step is taken within the framework of a materialistic economy. The technological world view also prevents abatement of the growing concern over climatic change. Our way of dealing with creation is preventing the gaining of a new perspective within which these problems can be lessened.

Werner Heisenberg (2000:181-182) has drawn an impressive picture of this situation.

With the seeming limitless expansion of material power man has arrived in a situation of a captain whose ship was so well constructed from steel and iron that the needle of his compass reacted only on the iron mass of the ship and no longer pointed to the North. With such a ship the correct direction can no longer be established, it simply circles around or is at the mercy of wind and currents.

We have abandoned our culture in favor of this lack of orientation. Man undoubtedly has received power, but the threatening devastation increases. Technological advancement per se can turn itself against man and his environment. This threatening frequently hides behind the desired superiority of technological effectiveness and economic efficiency. The ethical reduction implicit in it is scarcely recognised.

\section{The cosmological and the ethical deficit}

I have just stated that the current view of life is fed by the spirit of the Enlightenment. This undoubtedly has given us much benefit, but also much evil. Put very generally, I would like to say that the current approach to technology, in my view, suffers from a cosmological deficit and an ethical deficit. Reality is frequently reduced to a scientific-technological controllable reality. That amounts to a positivistic cosmology or a techno-cosmology. In this one-sidedness too little justice is done to the many-sidedness of full reality and to its dependence on and its involvement with the divine Origin.

Besides a cosmological shortfall we also have to face an ethical deficit. Reality around man is seen as made of things converted to objects of manipulation. The technological mode of thought reduces everything to the status of a useful object. The inherent value and 
meaning thereof is emptied into the benefit that man can derive from reality. This ethical deficit is best characterised as the ethical deficit of love, because justice is not done to the inherent nature of things.

\section{Enlightenment of the Enlightenment: "In your light we see light"}

In general, as has been discussed, silence is being maintained on the deepest background of the current technological culture and on the present ethics of technology. However, the motive of the Enlightenment is still dominant. Therefore, when people criticise the technological culture the Enlightenment cannot be ignored.

If it is true that the crisis of the technological culture resides in man's scientific-technological involvement with nature, this crisis also points to a crisis in the autonomy postulate of the Aufklärung. It increasingly becomes clearer that the culture cannot maintain absolute freedom and absolute controlling power. In a sense a religious substance is required.

In the reformational philosophy we have a tradition of fundamental criticism of the Enlightenment as a result of the pretension of human autonomy. Although we cannot reverse the Enlightenment we will have to acknowledge its devastating action and to ethically reschematise its positive results. Can the cosmological and ethical deficit be revoked? This will require an approach different from current thinking. With Rohrmoser I would like to make an appeal for an enlightenment of the Enlightenment. Or, to put it in terms of Psalm 36: "In your light we see light" (Ps. 36:9). The Aufklärung must itself be illuminated by the divine light of Revelation. To again refer to Heisenberg's metaphor of the ship: if the captain desires to sail in the right direction once more, he will have to orientate himself by using the stars. Thus, the technological culture will again have to be considered with reference to viewpoints from outside technology.

\section{Revoking cosmological and ethical deficits}

It will become clear that we hold the opinion that the cosmological and the ethical deficits resulting from a reductionistic scientific approach to reality, cannot be resolved by another, for instance expanding scientific approach. However, much systems thinking is presented as a holistic approach, and while there is appreciation for its merits, it remains an abstract scientific approach from an anthropocentric position. A widening of more dimensions is necessary - in other words, a more comprehensive holistic 
approach. The whole of reality has to be recognised as a created given reality that precedes science. This reality does not rely on itself, but is in all respects dependent on and involved with the divine Origin.

The most intimate involvement of God with created reality is characterised by his love. Acceptance of the unity in love repeals the ethical deficit of love in the current ethics of technology. It is not by accident that, in the Christian religion, the command of love for God and the neighbour contains the essence of all motives, commands, values and norms. Also, in technological development, this dual love must unify. This means that from the start everything must be appreciated according to its nature. Apart from regard for values and norms, this also ensures attention to context-values: the ecological and social values.

We will have to trace what the repealing of the cosmological and ethical deficit means for the development of technology.

\section{A renewed cultural picture}

Which picture that preceded science and technology can help us to see how we can reposition ourselves in technological development? The cultural philosopher Hans Jonas can be helpful. Imagine, he says, that we were on the moon. We would then be impressed by the immenseness of the cosmos. From the moon the extreme unicity of the earth in the gigantic cosmos will be conspicuous. It is the only green planet in our solar system. A multiplicity of life is present. If we, as moon travelers, want to survive, we will have to return to earth. From the moon, says Jonas, we find to our horror that planet earth is in danger. The exceptionality of life is threatened by the present technological-economic development. Change is necessary. Technology and economy may not threaten life, but must rather serve life.

A responsible cultural development summons a representation of culture that depicts earth as a garden tended by humans. Foremost in that picture is an unbreakable cohesion and the inherent value or nature of everything. The intrinsic values must be respected before we involve scientific-technological activities. Every human activity should begin with a caring relationship and respectful treatment. Creation and creature have to be treated according to their nature, otherwise life will flee. This is not idolisation of nature. On the contrary, it is a recognition of the caring of the Creator, which has to be answered by humans. 
The garden metaphor also reflects the alliance and dependence of man on the whole of creation. Reality has been given to man as a present; man may not be lord and master, but must act as keeper and minder. He may develop and reveal creation as one would carefully open a big present. This is the way man must treat the present of God's earth. It means that especially technology and the economy is taken into service by all that lives.

The picture of the garden also clearly links to the original meaning of economos. We should care, cherish, protect and conserve as part and parcel of harvesting, building and producing. In the cultural paradigm of the controlled garden, upscaling and cultural acceleration will, in terms of scale and pace, be transposed to levels that will benefit the coexistence of man and creation. In the picture of the garden, the limits of the carrying capacity of nature is respected. Responsible cultural development means living on the interest of the given capital, but excludes using or depleting the capital itself. Usufruct - using the interest and not the capital indicates the direction for a more sustainable cultural development. Sustainability is possible within the metaphor of the garden: this means that technology together with economy must refrain from manipulation, extortion and pollution. As the economist Herman Daly of the World Bank puts it, sustainability must maintain the fruitbearing capacity of the earth and thus possibly increase it and must limit withdrawal to usufruct, which has to be offered to all humans, now and in the future. A more harmonious development could start in which ecology, technology and economy are in equilibrium. Technology and economy will thereby have to be placed in a different ethical context.

This is a start for a new cultural transformation. It amounts therefore, to a fundamental re-orientation of the technological-economic order. It allows room for growth that is more proportional and selective. Apart from technology and economy in building and producing, more attention is required for maintenance, for protection, conservation, for guarding and caring. Thereby the diversity of life forms in the plant and animal kingdoms can be preserved. Technology and the economy must be developed within the perspective of the earth as one large garden-city. Technology ought not to be a central value, but a pré-value as a condition. 


\section{Ethics of responsibility: revoking the ethical deficit}

The question that now needs answering is which ethical approach is the fittest to revoke the described ethical deficit of love in the current ethics of technology.

I believe an ethics of responsibility is the most appropriate approach for an ethics of technology.

The word responsibility is very apt, because it indicates that everyone who is involved in scientific-technological development must assume the role of envoy. It means that in an ethics of responsibility there is scope for calling. Calling especially emphasises positive instruction. While ethics is associated with "what may not be allowed" in actual discussions on problematic development, within the context of "responsibility ethics", a start has to be made to place emphasis on the positive. It is aptly said that, by means of new technological possibilities to alleviate human suffering or distress, the ethical conception of possible help changed to an ethical obligation. In general, a good starting point for an ethics of responsibility seems that the "actors" must be aware of the positive scope of their action in or with technology. In the first place the point at issue is rendering and keeping the world habitable, to provide the necessities of life and the alleviation of need and suffering.

Successively I would like to give brief attention to the implications of an ethics of responsibility for motives, values and norms.

\subsection{Renewing of motives}

In the perspective of the garden-development, man should direct his cultural activities away from himself in love for God and the neighbour; then the motives for the different cultural activities will acquire new contents instead of the central motive of power, in which man circles around himself in self-interest. A central motive of love will provide direction. What follows is a divergence of the different cultural activities. This implies that in science the pursuance of wisdom should be the prime objective, and in technology it should be building and conserving. Therewith the different responsibilities of science and technology are guaranteed. This divergence is the way to achieve meaningful, flourishing cultural activities.

I would like to explicate these authentic values for science and technology. 


\subsubsection{Science: growth in wisdom}

Only when recognition of the Origin and the meaning of reality precedes and colours the practicing of science - the viewing of the given reality as a maintained garden - will instrumentalistic science be rejected and will science be positioned in a correct relationship to the full experiential reality. It has to be integrated with the full experiential reality, thereby deepening experiential knowledge. In other words, scientific knowledge will then serve growth in wisdom.

\subsubsection{Technology in the service of individual and societal life: technology as prosthesis}

What I have said of science in general, also applies to technological science. It may also not serve as instrument of scientifictechnological control. This will not rob technology of its distinct character or meaning. Technology should not be the result of an instrumental use of science or application of science, as is frequently said. Those are visions that will rather derail technology or that will ignore this derailment instead of providing room for justified responsible technology development.

Similar visions also diminish the place of invention in technological development. It has been said that invention is the heart of technology. It means that human creativity must not allow science to restrict it, but must be fed and even stimulated by old and new scientific knowledge. It would be useful to, even in the training of engineers, pay more attention to justified creativity in invention and innovations in order to render technology more serviceable to life. The motive in technology should be usefulness to life and society. Technology must, as it were, both individually and collectively, serve as a prosthesis. Then man will retain a say over technology. Not only small scale technology has to be considered. Therefore, wherever possible, subterranean building should be suggested if the milieu can thereby be saved, and human society will experience less discomfort.

\section{2 Other values (ecological, technological and social)}

For a justified, responsible technology the ethical challenge is finding, not only true motives, but also milieu values, technological values and social values.

Ecological values include the preservation of biodiversity, clean water, soil and air, the fertilisation of soils, and improving the life 
milieu. The biosphere must remain intact and therefore a war must be waged against dangerous emission gases.

Technological values include habitability, the provision of basic necessities of life, for instance food and health, a battle against suffering and illness, a fight against threats from nature and a focus on healing, sustainability, lessening physical work burdens, etcetera. Beyond our physical wants, real meaning fulfillment is found in spiritual growth, personal relations and communal life.

Social values are communal meaning, sobriety, justice, considerateness, strengthening information and communication and therefore, social welfare in general. Is it too daring to suggest that "rest", "having time" and "spiritual revival" must also be mentioned here as the unused chances of modern technology?

\subsection{Integral framework of norms: simultaneous and plural application}

With reference to technological development I have up to now given attention to the cultural picture, motives and values that have to be considered: technology has to be serviceable to a great number of life forms, befitting a healthy "garden development". A connection with the existing situation must always be sought.

The normative principles are derived from the cosmology of the reformational philosophy and form a guide for responsible technological development. The norms are the cultural-historical norms, the norms of effectiveness, the norms of information and communication, of harmony, of efficiency, of caring and respect. In my publications I have given these much attention (see Schuurman, 1995:96-101).

\section{Consequences for reorientation for technology}

I now wish to treat the consequences of the new approach to culture. It has to be remembered that until now I have placed two "ideal-type" cultural paradigms or perspectives or images against one another. In reality no such absolute contrast exists.

From the metaphor or perspective of the earth as a garden, a clear relationship can be found. The technological world view parasitises on reality as created reality. It causes disturbances from which it can never free itself. That is the reason why much flexibility can be observed within the technological world view. Luckily there are 
instructive inconsistencies to reflect on. Conversely: those who recognise a created reality, are still frequently bound to the technological world view. This complicated situation makes clear that the choice of the correct direction is a never-ending mandate that implies a struggle and excludes indolence.

Although the stressing of another perspective remains important for the philosopher, it would be legitimate to enquire about the consequences for the praxis of this ethical-philosophical view and about the differences from those views which are currently held.

\subsection{Priorities}

It is common in science and technology to strive for the remarkable. This leads to violation of justice by giving less attention to technologies that could help people in their struggle against hunger and illness. It is a shame to see that possible solutions for these problems receive less attention and money than money-squandering prestigious projects concerned with astronautics, such as space flights to far-off planets. These enterprises are interesting, but should we not rather fulfill our ethical commitments by reprioritising? To name another example of injustice: should we not say that our given raw materials require an equitable redistribution in order to allow the poor and needy to share in them? This prioitising will confirm that there is enough for everyone: "There is enough for every need, but not for every greed."

\subsection{Ecological, social or culturally adjusted technologies}

From within the stated motives modern technology should join with the given situation in which man, culture, nature, milieu and, for example the landscape, find themselves. Therefore, modern technology must be ecologically responsible, and therefore be appropriate technology. This kind of technology, in comparison with current development, will have to undergo broadening. Technology should not come into conflict with the condition of cultural development and its rich variation, but must join it in its development in order that the adapted technology may simultaneously enrich this culture. It is a pity that, in the developing countries, we have to report the contrary. In these countries modern technology frequently leads to a break with existing culture.

I therefore find it unfortunate that the influence of Schumacher, with his call for the wider application of appropriate or small technologies, receives little attention. A caricature has been made of him. 
Schumacher $(1973 ; 1977)$ did not imply a return to primitive and prescientific technology, but wanted a technology that combines with nature, with culture and a technology that fits the human scale. Therefore, subject to external boundaries and human restrictions we have mighty powers and forces at our disposal, but we remain dependent on fragile ecosystems. This is frequently not considered by existing technological-economical forces, with known serious consequences. Therefore we must, with a view to a healthy future, maintain that a creative, inventive technology is required that is economically productive, that is ecologically and culturally adjusted, socially fair and which offers personal fulfillment. It will even be possible to integrate these technologies with computer technology or the Internet, because by means of these technologies decentralisation of power rather than its concentration is possible.

\subsection{Ecological or organic agriculture}

The problems of industrial agriculture are so massive that the catastrophe sketched above could become real, unless a switch is made to biological or ecological agriculture.

In industrial agriculture we are frequently guilty of technologising. On the one hand modern technology leads to lower production costs, but on the other hand the increased production leads to damage to the farmer, animals, nature and the milieu. Surplus production causes uncertainty in agriculture with respect to future possibilities, loss of animal welfare, over-fertilisation, impoverishment and pollution of the soil, new sicknesses of the soil, disturbance of the landscape, pollution of the milieu, loss of biodiversity and a bleak future for rural areas. While, in agriculture, a living reality is involved, we have been viewing it as inorganic. Agriculture in the grip of the scientific-technological control ideal, has been divorced from the ecological, biotic and cultural context.

In biological and ecological agriculture people want to repair the good relationship. Qualitatively, good products and profit for the environment can go together. In this agriculture there is no relapse to earlier periods, but, with a qualitatively higher input of biology and soil science, people will involve themselves more wisely with soils, plants and animals. The fertility of soils is hereby promoted.

\subsection{Genetic manipulation}

The absence of a normative framework for new technologies is especially evident in the introduction of genetic manipulation of 
plants, animals and humans. Genetic manipulation must be treated more critically and must be ethically and juridically curtailed. The present development is unpredictable and risky and possibly irreversible in its negative consequences. A model different from the technological model must be used when living organisms are involved. The best would be to develop an organic paradigm for the judging of new possibilities. A shift of paradigm will already be better because the organic model has life as its point of departure, while the technological model ignores life in principle.

\subsection{Alternative energy, sustainable energy and dematerialisation}

When we, on the one hand, see the relativeness of science and technology and, on the other hand, the existing dangers, we become more creative in the development of alternatives. Thus we develop energy sources that renew themselves, e.g. wind and solar energy. By not allowing loss of material we advance the possibilities of recycling.

\subsection{Dilemmas}

Dilemmas can become acute when technology is re-orientated. Research aimed at rendering safe the radio-active wastes from nuclear power stations must continue with a view of using these facilities responsibly. These plants will, however, also have to be controlled more effectively. Energy generation can be considered from sustainable sources in contrast with the fossil fuel currently used. As long as radio-active wastes cannot be made safe technologically, nuclear energy will remain very dangerous.

\section{Political consequences}

Before I conclude, it is necessary to make one further remark about the context in which the development of technological science and modern technology takes place. Within a "free market economy" the sketched ethical context must be followed if people understand "freedom" as "freedom with responsibility". Reality, however, teaches us that economic power favours or even strengthens technicism and technicisation. Many people look towards politics to counter this. But materialistic politics also strengthens the same process. But involving politics is the right way to place "derailments" on the agenda, because the running of the state concerns everyone and the state also has the power to restrict economic enterprises. Politics must, however be tuned to the sketched normative context 
and must, according to the nature of politics, focus on law and public justice. In connection with the present dislocated situation the brakes will have to be applied to the technicisation process. Via politics people can choose another direction for technology, for a broadly normed and differently constituted technology, friendlier towards the milieu, nature, animals and culture. Ethically just actions are then juridically enforced. It has further to be acknowledged that such national politics can only be effective provided it is - given our globalising culture - based on law and public justice and supported in the international political arena. The prophetic message of Amos is of current interest: "But let justice roll on like a river, righteousness like a never-failing stream" (Amos 5:24).

\section{Struggle and hope}

Finally I hope that I have not given the impression that the sketched perspective can be fully realised by us. It will, however, be enlightening during cultural problems and cultural threats. Thorns and thistles will continue to accompany our work. Until, through God's intervention, the developed earth, once characterised by distortion, will be transformed to the divine garden-city (Rev. 21:922:5), where men will be revealed as sons of God, freed to the glory of the freedom of children of God (Rom. 8). In an unexpected way it will then be clear that the work in science and technology, in spite of man himself, will be involved in the recreation. Such a perspective gives hope and places us under obligations. The hope and obligations present an inspiration for another ethics in which people are asked to take their responsibility to seek the meaning of technology, not in isolation, but contained in the full meaning of reality: the Kingdom of God. Such an ethics must be told and heard in our contemporary world. The toughest struggle may be in the ethics of technology.

\section{List of references}

BARBER, IAN. 1993. Ethics in an age of technology. San Francisco: Harper. HEISENBERG, WERNER. 2000. Das Naturbild der Heutigen Physik. Rde. 8, p. 22; on the model of Staudinger, Hugo. Stein am Rein: Christiana Verlag. (Geschichte kritischen Denkens.)

JONAS, HANS. 1984. The imperative of responsibility: in search of an ethics for the technological age. Chicago: Chicago Press.

MITCHAM, CARL, ed. 1989. Ethics and technology. London: Jai Press. (Research in philosophy and technology, 9.)

SCHUMACHER, ERNST F. 1973. Small is beautiful. London: Blond \& Briggers. 
SCHUMACHER, ERNST F. 1977. A guide for the perplexed. London: Jonathan Cape.

SCHUURMAN, EGBERT. 1995. Perspectives on technology and culture. Sioux Center: Dordt.

SCHUURMAN, EGBERT. 2003. Faith and hope in technology. Toronto: Clements.

SCHUURMAN, EGBERT. 2005. The technoloical worldpicture and the ethics of responsibility. Sioux Center: Dordt College Press.

TILLICH, PAUL. 1986. The spiritual situation in our technical society. New York: Scribner.

VANDENBURG, WILLEM H. 2000. The labyrinth of technology. Toronto: University of Toronto Press.

\section{Key concepts:}

ethics of responsibility

ethics of technology

religion and technology

Kernbegrippe:

etiek van tegnologie etiek van verantwoordelikheid godsdiens en tegnologie 
